\title{
The Role of the Police in Managing the Crime of Child Molestation during COVID -19 Pandemic (Study in Trenggalek District Police Legal Area of Indonesia)
}

\author{
Arini Dwi Agus Bintari Ningrum ${ }^{1}$, Setiyono², and Teguh Suratman ${ }^{3}$ \\ ${ }^{1-3}$ Master of Legal Science Postgraduate Program, \\ University Of Merdeka Malang \\ Indonesia
}

\begin{abstract}
Cases of sexual violence such as rape and child molestation are rife during the Covid-19 corona virus pandemic. Based on data from the Indonesian Child Protection Commission, 19 cases of children who violated the law were victims of sexual violence in 2020. The second order was children who experienced physical violence, namely 9 cases in 2020. Various efforts have been made by both the government and the community to eliminate crime and violence. sexual relations, in particular sexual crimes and violence against children. However, these efforts can only reduce the intensity of the crimes committed, not stop sexual crimes or obscenity. This article uses an empirical legal research method because it examines the role of the Police at the Trenggalek Police in tackling the crime of obscenity. Practical juridical approach examines legal provisions that occur in practice or reality in society [5]. Primary and secondary data were used, and the initial data was obtained by interview method with open and closed questionnaires. The role of the police is small in preventing the crime of obscenity through serious efforts such as outreach and appeals to the community. Furthermore, several inhibiting factors in overcoming the crime of child molestation are a) the current COVID-19 pandemic. b) Technology and social media are developing rapidly. c) Direct socialization by the Trenggalek Police to the community about the importance of preventing child molestation is still rare. Suggestions that can be recommended are that in the future police officers in Trenggalek District in carrying out their programs need to collaborate with relevant agencies such as schools, and related agencies of the Trenggalek Regency Government.
\end{abstract}

Key words: Police, Work Crime, Children.

\section{INTRODUCTION}

Cases of sexual and violent crimes are a matter of concern in Indonesia. Based on data from the Indonesian Child Protection Commission on 18 May 2021, cases of sexual violence such as rape and child molestation were rife during the Covid-19 coronavirus pandemic. Based on data from the Indonesian Child Protection Commission, 19 cases of children who violated the law as victims of sexual violence in 2020. The second order was children who experienced physical violence, namely 9 cases in 2020. A total of 119 children became victims of psychological violence. Twenty cases of children who became victims of sodomy/pedophilia and kidnapping each became a victim. At the same time, 12 cases became victims of murder and possession of dangerous weapons ${ }^{[1]}$. From these data, it can be concluded that sexual or immoral crimes and violence are a very terrorizing specter for the community, especially women and children. Victims of sexual crimes are not indiscriminate. Even the perpetrators of crimes no longer pay attention to the status, age, education, rank, and position of the victim.

According to Annual Records of National Committee for Women in 2020, published on 5 March 2021, the number of cases of Violence against Women throughout 2020 was 299,911 cases, and cases of domestic sexual violence were 1,983 cases $(30 \%)$. In the Public or Community Domain, there were 962 cases (55\%) of sexual violence consisting of other sexual violence (or not explicitly stated) with 371 cases, and 229 cases of rape, 181 cases of sexual harassment, 166 cases of sexual abuse, and sexual intercourse 166 cases. Five cases and the rest were attempted rape 10 cases $^{[2]}$. 
From these data, it can be concluded that sexual or immoral crimes and violence are a frightening specter for the community, especially women and children. Victims of sexual crimes are not indiscriminate. Even the perpetrators of offenses no longer recognize the status, age, education, rank, and position of the victim.

Child molestation can occur due to various factors. Some of these factors are Moral and religious factors. If a person is immoral and his religious teachings decline, this becomes one of the reasons for the sexual harassment of girls. So the lack of spiritual guidance and faith in humanity makes humans easily fall into bad behavior; Environmental and family factors. The influence given in the family environment and social environment can cause changes in children. For example, parents are the first environmental influences obtained by a child before the child gets to know the outside environment around where he lives. Therefore, the first environment that children absorb is the family environment. Attention and affection from parents play the most crucial role in the growth and development of children. Children growing and developing need a figure who can be a role model. The role of parents is more significant for the growth and development of their children so that children can avoid deviant behaviors. Lack of parental care for children can make children become victims of criminal acts of sexual harassment; Factor of media and technology. Technological developments have a positive impact and can also have a negative effect. The absorption of technological progress is the impact of globalization entering Indonesia. Children and adults can misuse the adverse effects of excessive absorption of technological developments. Recently, many pornographic popping up in the community, so there is a desire to imitate the actions they see in those pornographic films. Apart from the circulation of pornographic, another encouraging factor was the existence of books and reports in newspapers about the presence of the crime of obscenity, which also contributed to the emergence of this crime.

Many efforts have been made by both the government and the community to eliminate sexual crimes and violence, especially sexual crimes and violence against children. However, these efforts can only reduce the intensity of the crimes committed, not stop sexual crimes or obscenity. Perpetrators of sexual crimes are often categorized as close people or people who live in the victim's vicinity. For example, neighbors, friends, brothers or sisters (siblings), biological fathers or stepfathers, grandfathers, uncles, even teachers or closest people known. Cases of sexual abuse often occur because of a high level of lust, low faith from the perpetrator, and very shallow thoughts or knowledge.

Sexual and violent crimes called obscenity are immoral criminal acts committed by someone driven by a sexual desire to do things that can arouse lust. Meanwhile ${ }^{[3]}$ defines criminal acts of children molestation (sexual abuse of children) as any behavior that violates the norms of decency or low behavior, and all of those are in the environment of lust. As a result of this obscene crime, the victim gets destructive impacts, namely: a) Psychological pressure/psychological suffering such as loss of sense of worth to themselves due to obscenity cases they received, against how the school community and friends will see them, especially in the environment of family and stakeholders/essential parties. Other psychological stress can be anxiety, loss of self-confidence, loss of joy, overthinking or withdrawal from daily or everyday activities, growing hatred (aversion) towards the opposite sex, and excessive suspicion of others which shows the desire to do good to them. b) Physical suffering, meaning that the result of the crime of sexual abuse will cause injury to the child. Wounds are not only related to torn or injured vital organs (genitals), in addition to the possibility that there are other body organs/ limbs that also being damaged if the victim/child fights hard against the perpetrator to defend herself during the assault, which at the same time encourages the perpetrator to be more rude and cruel to suppress the resistance of the victim/child. The occurrence of violence in the crime of child molestation can cause specific trauma to the victim's body so that the victim suffered physical injuries, for example, bruises on the arms, legs, or other parts of the body. These harmful impacts of sexual and violent crime can be healed by psychological assistance to children, but it would be better if the crime of sexual abuse against children could be prevented and abolished. However, this is still difficult to be carried out given the increasing obstacles that exist.

Furthermore, in the provisions of Law Number 2 of 2002 concerning the National Police of the Republic of Indonesia, there is a formulation regarding the definition of the police. However, the purpose of the police is not fully explained because it only concerns the functions and institutions of the police as regulated in the legislation. Based on Article 1 of Law Number 2 of 2002 concerning the Police of the Republic of Indonesia, what is meant by the police are all matters relating to the functions and institutions of the police by statutory regulations ${ }^{[4]}$. The police have a critical task and authority, especially in law enforcement in Indonesia. In Article 13 of Law No. 2 of 2002 concerning the 
Indonesian National Police, it is stated that the main tasks of the Indonesian National Police are to maintain security and public order and enforce the law as well as to provide services, safety, and protection of services to the community. Furthermore, articles 14 and 15 have described in detail and thorough the primary duties and authorities of the Indonesian National Police. Hence, from some of the opinions above, it can be drawn in a straight line that the police is a person or government institution owned by the state that has the duty, authority, and responsibility to maintain security and public order and enforce law enforcement. From this point, we can see that the police also have a significant role in preventing sexual and violent crimes against children. In addition to judges, the police are also law enforcement officers who must protect children and enforce regulations against perpetrators of obscenity and violence.

\section{RESEARCH METHODOLOGY}

Based on the description in the introduction above, this article examines the role of the Trenggalek District Police in overcoming the crime of sexual abuse in District Trenggalek and identifies the obstacles faced by the police in overcoming the crime of child molestation.

This article uses an empirical legal research method because it examines the role of the Police in Trenggalek District Police in overcoming the crime of obscenity. A practical juridical approach examines legal provisions that occur in practice or reality in society ${ }^{[5]}$. Primary and secondary data are employed, and to obtain the preliminary data, it was done using an interview method with open and closed questionnaires.

\section{RESULT FINDINGS}

\section{The Role of the Police in Combating the Crime of Child Molestation}

Obscenity is a crime with the threat of severe punishment, but it still happens in society, even though in the threat of severe punishment, the act should be stopped or at least make the perpetrator take a very long consideration before committing the act. Child molestation is an immoral act regulated in Article 76D Jo Article 81 and Article 76E Jo Article 82 of the Law of the Republic of Indonesia No. 17 of 2016 concerning the stipulation of Regulation as Substitution to the Law No. 1 of 2016 concerning the second amendment to the Law of the Republic of Indonesia No. 232002 concerning Child Protection to be drafted as a law.

Based on data collected by the Ministry of Women's Empowerment and Child Protection, violence against children in 2019 occurred as many as 11,057 cases, as many as 11,279 points in 2020, and 12,566 cases as of November 2021. In statistical data at the Ministry of Women's Empowerment and Child Protection, it was noted that among children, the most common cases experienced were sexual violence at 45 percent, psychological violence at 19 percent, and physical violence at 18 percent.

According to the annual records from the National Committee for Women, it is known that the level of child abuse has the highest rank in the graph of sexual violence in the category of Domestic Relations/Personal Relations domain. Different from 2020, where there were 166 cases of child molestation, in 2021, the number of child molestation cases increased to the top rank, which is as many as 412 cases $^{[6]}$.

Based on the results of the interviews that have been collected, the researchers analyzed the role of the Trenggalek District Police in resolving the crime of sexual abuse to children. There are 11 cases of child abuse recorded at the Trenggalek District Police. The police, especially the Women's and Children's Service Unit, are not directly concerned with socializing the prevention of child molestation, both within the Trenggalek District Police and in the community. One of the factors causing the high rates of child molestation in District Trenggalek is the lack of public education.

The Trenggalek District Police does not prioritize preventive efforts and focuses only on strict enforcement. Even though the role of the police has been clearly stated in Article 13, Article 14, and Article 15 of Law No. 2 of 2002 concerning the Indonesian National Police, the police are tasked with maintaining public security and order, enforcing the law, and providing protection, safety, and service to the public. Thus, community development efforts through socialization are also one of the tasks of the police. Unfortunately, this has not been implemented properly, so in this case, it can be said that the role of the police in resolving criminal acts of sexual abuse against children is still lacking. Based on this finding, the efforts of the police are still very much needed in overcoming the crime of child molestation 
through several natural movements such as socialization, strict action, and appeals to the community so that there are no more cases of child molestation. The police need to make socialization efforts aimed at the public about the existing legal rules in Indonesia, especially regarding sexual abuse against children, so that people know, be more careful and avoid it. Socialization aimed at children also needs to be done considering the knowledge of children in District Trenggalek about child molestation is still significantly less, since based on the data, it is known that many of the children who are victims do not see that they are being molested. The police need to go directly to the field to provide socialization to the community to pay more attention to preventing children molestation. In addition, firm action from the police also needs to be implemented and improved so that all cases that have occurred become examples that the crime of sexual abuse of children will receive strict punishment according to the applicable law and not be committed by anyone in the community. The appeal by the police to the community also needs to be constantly made to warn the public to avoid criminal acts of sexual abuse of children and continuously maintain, protect and provide knowledge to children or their younger siblings about the dangers of child molestation. This is also to urge the public to report it to the authorities immediately if they see/know and feel that there has been a criminal act of sexual abuse against a child.

Furthermore, related to the existing obstacles in overcoming the crime of child molestation that occurred in District Trenggalek, where the police admitted that their officers encountered several obstacles, especially in handling cases of child molestation. The First Obstacle is the current pandemic situation. It is undeniable that the impact of the COVID19 pandemic is vast and occurs in various sectors and what happened in the Trenggalek District Police. This pandemic also affects the performance of the police in District Trenggalek. The COVID-19 pandemic has narrowed the space for the police to handle cases of child molestation. The Second Obstacle is technology and social media, which are proliferating. Due to this pandemic, people depend on everything in their lives and daily activities in cyberspace. This virtual world is vast and difficult to monitor intensively. Many crimes are committed through social media. Particularly with the current condition where children have to be introduced to social media to support their daily activities, such as the teaching and learning process. However, unfortunately, parents and older siblings cannot intensively control the use of social media by children. Most parents and police officers are "misled" in their monitoring so that crimes are still often committed through social media.

The Third Obstacle is the direct socialization by the Trenggalek District Police to the community regarding the importance of preventing the crime of sexual abuse of children. Socialization is one of the means to educate the public on the importance of preventing child molestation. However, unfortunately, the police have not realized this program. Due to this obstacle, many people are still blind to the law and do not pay attention to their children's behavior. Therefore it becomes an obstacle for the Trenggalek District Police in terms of the law enforcement because there may still be cases that have not been revealed. For example, unscrupulous clerics carried out the case in Subdistrict Pule to 34 of his students. Due to lack of education, female students who get abused are silent and do not know that an incident is a criminal act of sexual abuse against children. It shows that the knowledge possessed, especially by children, about abuse and criminal acts of obscenity is still very lacking; hence it is necessary to carry out socialization to children from the earliest possible age. The Fourth Obstacle is the socialization program that has not been implemented properly under the reason of inaccessibility to the location and unsupportive infrastructure. District Trenggalek has an area of 1,261.40 km2. District Trenggalek consists of 14 sub-districts, five sectors, and 152 villages. This condition has been quite a limitation in conducting socialization and appeals. Moreover, Trenggalek is a district consisting of many mountains. Access to areas on the outskirts of districts/cities is still complicated. Most of the crimes of child molestation occur in sub-districts located in outlying areas, for example, in sub-districts Dongko and Pule. So direct socialization is still difficult to conduct because it is hampered by location and time. In addition, direct supervision is also difficult, considering the location is in a mountainous area. In addition to location and time, facilities and infrastructure still lacking are inhibiting factors in overcoming child molestation. Because the location is in the mountains and the existing infrastructure is still minimal, it creates obstacles in overcoming the crime of child molestation. The Fifth Obstacle is the lack of knowledge and awareness of parents about preventing the sexual abuse of children. Parents are a significant factor in a child's life. If parents do not give enough attention and are open to their children, it will be difficult to open up to their parents. So that if there is a crime of sexual abuse experienced by a child, it will be difficult for parents and police officers to know because the child is reluctant to tell stories. This 
makes it difficult for the police to conduct investigations and arrest the perpetrators/suspects. Then the implementation process of overcoming the crime of child molestation will also be hampered. Due to the obstacles above, overcoming the crime of child molestation cannot run smoothly, whereas the crime of child molestation needs to be eradicated and eliminated. It can be seen that the issue of child molestation crimes needs serious attention by the community and also the police because the crime of sexual abuse experienced by children can have a bad impact on children and can be overcome with psychological assistance to children. However, it would be better if the crime of sexual abuse against children could be prevented and abolished. However, this is still difficult to realize given the increasing obstacles. These obstacles should be a concern for the community and law enforcement officers, especially for the police, so that efforts are made to overcome them. The draft of policies and programs owned by Police agencies should be oriented for the community. So that the process of implementing the prevention of child molestation that occurred in District Trenggalek can run according to the expectations of all parties.

\section{CONCLUSION}

Based on the description of the results and discussion, it can be concluded as follows: Namely the role of the police in efforts to overcome the crime of sexual abuse against children, it can be said that it is still very minimum and limited. The police have a minor role in preventing obscenity crime through genuine efforts such as socialization and appeals to the community. On the other hand, preventive measures that the police can carry out to overcome child molestation are through socialization, strict action, and appeals. Furthermore, several inhibiting factors in overcoming the crime of child molestation are a) The current COVID-19 pandemic. b) The rapidly growing technology and social media. c) Direct socialization by the Trenggalek District Police to the community about the importance of preventing child molestation is still rare. d) Locations that are difficult to access and limited infrastructure. Access to areas on the outskirts of districts/cities is still complicated. e) The lack of knowledge and awareness of parents on preventing criminal acts of sexual abuse against children. These obstacles should be a concern for the community and especially for law enforcement officers so that the process of implementation for resolving the crimes of molestation against children that occurred in District Trenggalek can run as expected. Therefore, the sexual abuse of children in District Trenggalek can be eradicated.

The suggestions that can be recommended are that in the future, the police officers in District Trenggalek, in carrying out the program, need to collaborate with relevant agencies such as schools, and the applicable Service Office of the District Trenggalek Government.

\section{REFERENCES}

1. Statistical Data of the Indonesian Commission for Children Protection on 18 May 2021, https://databoks.katadata.co.id/datapublish/2021/05/27/case-kerasan-sexual-terhadap-anak-mendominat-saat-pandemi -covid-19

2. National Committee for Women, https://komnasperempuan.go.id/siaran-pers-detail/catahu-2020-komnasperempuan-lembar-fact-dan-poin-key-5-maret-2021

3. R. Soesilo, 1996, the Criminal Code (KUHP) and its complete commentary, article by article, Bogor, Politeia. Page 212

4. H. Pudi Rahardi, 2007, Police Law [Professionalism and Reform of the Police], publisher of Laksbang Mediatama, Surabaya, page 53.

5. Bambang Waluyo, 2002, Legal Research in Practice. Jakarta, Sinar Graphic, Page 15

6. National Committee for Women, https://komnasperempuan.go.id/ 